\title{
PKM PENINGKATAN PRODUKSI PADI SAWAH MELALUI SISTEM TEKNOLOGI PENGELOLAAN TANAMAN DI DESA PERUAN DALAM
}

\author{
Yakobus Bustami, Florentina R Esti Wahyuni \\ STKIP Persada Khatulistiwa Sintang \\ ybustami07@gmail.com, esti-pandi@ymail.com
}

\begin{abstract}
The rice plant (Oryza sativa L.) is the main food crop in Indonesia that can contribute 40$80 \%$ calories and $45-55 \%$ protein. Therefore, there should be an effort to increase rice production, especially paddy rice. One component of the technology applied for achieving the quantity of crops in the village of Peruan Dalam is currently the plant management technology system. This system can help rice farmers to increase rice production that has been felt by the people of Peruan Dalam. Community service activity (PkM) was held in October 2017. The activity of PkM was attended by village officials, community and students who participated in PPL and KKM activities in Peruan Dalam village. The results of this PkM activity get a positive response from the community. The community is very enthusiastic to follow this activity from the beginning to the last activity. This activity is expected to be developed continuously in order to increase rice production which has been needed so far.
\end{abstract}

Keywords: Oryza sativa L, management technology system, community service activity.

Tanaman padi (Oryza sativa L.) adalah tanaman pangan utama di Indonesia yang dapat menyumbang 40-80\% kalori dan $45-55 \%$ protein. Karena itu, perlu ada upaya untuk meningkatkan produksi beras, terutama padi. Salah satu komponen teknologi yang diterapkan untuk mencapai jumlah tanaman di desa Peruan Dalam saat ini adalah sistem teknologi pengelolaan tanaman. Sistem ini dapat membantu petani padi untuk meningkatkan produksi beras yang telah dirasakan oleh masyarakat Peruan Dalam. Kegiatan pengabdian masyarakat (PkM) diadakan pada bulan Oktober 2017. Aktivitas PkM dihadiri oleh pejabat desa, masyarakat dan mahasiswa yang berpartisipasi dalam kegiatan PPL dan KKM di desa Peruan Dalam. Hasil dari kegiatan PkM ini mendapat respon positif dari masyarakat. Masyarakat sangat antusias mengikuti kegiatan ini dari awal hingga akhir. Kegiatan ini diharapkan dapat terus dikembangkan untuk meningkatkan produksi beras yang selama ini dibutuhkan.

Kata kunci: Oryza sativa L, sistem teknologi manajemen, kegiatan pengabdian masyarakat.

\section{PENDAHULUHAN}

Tanaman padi (Oryza sativa L.) merupakan salah satu tanaman pangan utama di Indonesia dengan tingkat produksi maupun konsumsi menempati urutan pertama diantara komoditas pangan lainnya. Tanaman padi merupakan tanaman penghasil beras yang digunakan sebagai makanan pokok masyarakat
Indonesia pada umumnya dan kabupaten Sanggau pada khususnya.

Sekitar 90 persen (\%) masyarakat atau penduduk Indonesia menggunakan beras sebagai bahan pangan pokok karena beras dapat menyumbangkan 40-80\% kalori dan $45-55 \%$ protein. Sumbangan beras dalam mengisi kebutuhan gizi tersebut makin besar pada lapisan 
http:/jumalstkippersada.ac:id/jumal/indexphp/JPMR

penduduk berpenghasilan rendah (Koswara, 2009).

Mengingat pentingnya kebutuhan akan beras maka dari tahun ketahun selalu mengalami peningkatan seiring dengan pertambahan jumlah penduduk. Namun, produksi padi belum dapat memenuhi kebutuhan masyarakat terutama di desa Peruan Dalam. Hal ini disebabkan karena beberapa kendala diantaranya: (1) adanya aturan yang tidak memperbolehkan masyarakat membakar ladang, (2) adanya peningkatan populasi gulma yang tumbuh dengan rapat, (3) serangan hama dan penyakit yang sulit dikendalikan serta pemanfaatan pupuk yang belum berdaya guna yang kemudian berdampak terhadap penurunan produktivitas. Oleh karena itu, perlu adanya upaya untuk mencari terobosan teknologi budidaya yang mampu memberikan nilai tambah dan meningkatkan efisiensi usaha.

Salah satu komponen teknologi yang dapat diterapkan untuk pencapaian kuantitas hasil panen saat ini adalah sistem teknologi pengelolaan tanaman. Sistem teknologi pengelolaan tanaman merupakan salah satu komponen teknologi pada penerapan Pengelolaan Tanaman Terpadu (PTT) sehingga dapat meningkatkan hasil panen padi (Kristamtini dkk, 2011).
Sistem teknologi pengelolaan tanaman dapat mengurangi kemungkinan serangan hama, menekan serangan penyakit, menambah populasi tanaman, meningkatkan produktifitas padi $12-22 \%$ (Bobihoe, 2013). Sistem teknologi pengelolaan tanaman merupakan rekayasa teknologi yang ditujukan untuk memperbaiki hasil usaha tani padi yang merupakan perubahan dari jarak tanam sistem tegel (biasa) menjadi tanam jajar (Lalla, Saleh, Ali, Saadah, 2012). Tanaman jajar menambah populasi tanaman dan meningkatkan hasil produksi dari sistem tanam biasa. Tanam jajar memberikan beberapa keuntungan diantaranya: memberi kemudahan dalam pengendalian gulma, penggunaan pupuk lebih berdaya guna serta pengaturan air lebih efisien.

Berdasarkan permasalahan yang terungkap pada latar belakang tersebut, maka perlu dilakukan kegiatan penyuluhan kepada masyarakat dengan judul "Peningkatan Produksi Padi Sawah Melalui Sistem teknologi pengelolaan tanaman Desa Peruan Dalam". Kegiatan ini sangat penting karena sekarang ini banyak sekali kendala masyarakat terutama Desa "Peruan Dalam" dalam meningkatkan produksi padi.

\section{METODE PELAKSANAAN}


Kegiatan ini dilakukan pada bulan Oktober 2017 di desa Peruan Dalam dengan memberikan penyuluhan terkait peningkatan produksi padi sawah dengan sistem teknologi pengelolaan tanaman. Setelah memberikan penyuluhan, masyarakat juga dibimbing dalam mempraktekkan sistem teknologi pengelolaan tanaman dilapangan. Adapun langkah-langkah dalam sistem teknologi pengelolaan tanaman sebagai berikut:

\section{Pemilihan benih}

Memberikan pandangan terhadap memilihan benih yang bermutu. Salah satu cara pemilihan benih padi bermutu adalah dengan merendam benih dalam larutan garam dengan menggunakan indikator telur. Telur diletakan didasar air dan kemudian masukkan garam sampai telur mulai terangkat kepermukaan kemudian telur diambil dan benih dimasukkan kedalam air garam, selanjutnya benih yang mengambang dibuang. Teknik pemilihan benih dapat dilihat pada Gambar 1.

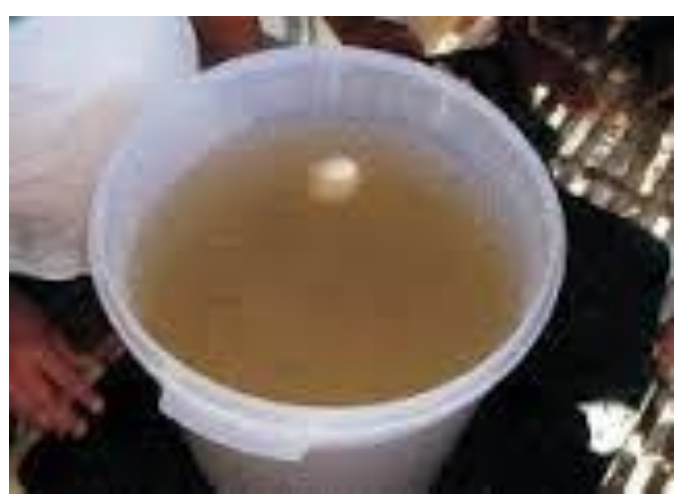

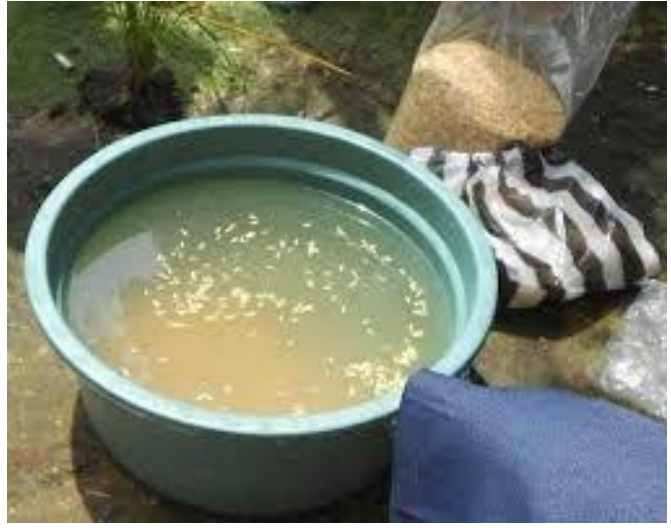

Gambar 1. Teknik pemilihan benih

\section{Pengolahan tanah}

Pengolahan tanah dilakukan dua kali yaitu proses pembajakan dan penggaruan. Proses pembajakan dilakukan dengan cara membalikkan lapisan tanah agar sisa-sisa tanaman seperti rumput, dan jerami dapat terbenam. Setelah pembajakan selesai dibiarkan selama satu minggu kemudian baru dilakukan penggaruan untuk melumpurkan dan meratakan tanah.

Tanah diolah dua minggu sebelum dilakukan penanaman dengan menggunakan hand tractor. Tujuan dari pengolahan tanah adalah untuk memperbaiki kondisi tanah, untuk memperlancar sirkulasi udara, terutama oksigen di dalam tanah agar menjadi lebih baik.

\section{Pesemaian}

Pesemaian padi disiapkan 18 hari sebelum dilakukan penanaman. Pesemaian dilakukan dilahan sawah (pesemaian 
basah), tanah untuk pesemaian diolah menggunakan cangkul kemudian diratakan menggunakan garu.

\section{Penanaman Sistem tanam jajar 4:1}

Bibit padi ditanam menurut garis caplak dengan arah tanaman mundur. Jarak tanam 11,5x23x46 cm, $46 \mathrm{~cm}$ jarak antar legowo ( barisan kosong), $23 \mathrm{~cm}$ jarak antar tanaman, $11,5 \mathrm{~cm}$ jarak tanaman dalam barisan dan dalam lubang tanam sekitar $1-3 \mathrm{~cm}$, bibit ditanam sebanyak 23 batang per lubang tanam. Pola sistem tanam jajar legowo disajikan pada Gambar 2 dibawah ini:
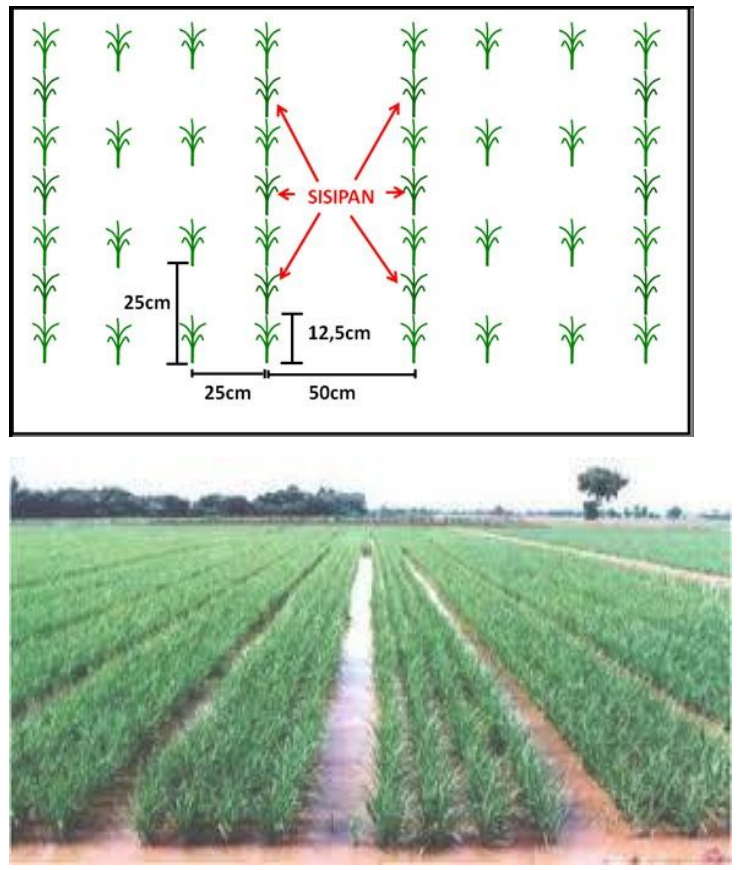

Gambar 2. Pola sistem tanam jajar

\section{Pemupukan dasar}

Pupuk yang diberikan adalah pupuk Urea $200 \mathrm{~kg} / \mathrm{ha}$, Phonska $500 \mathrm{~kg} / \mathrm{ha}$ dan TSP $200 \mathrm{~kg} / \mathrm{ha}$. Untuk dosis pupuk kimia yang dibutuhkan padi sawah dengan luasan lahan $500 \mathrm{~m} 2$ yaitu $10 \mathrm{~kg}$ Urea, 25 kg Phonska, 10 kg TSP. Pupuk Urea diberikan pada saat pemupukan dasar ( saat penanaman), pupuk Phonska diberikan saat tanaman berumur 21 hari setelah tanam dan pupuk TSP diberikan saat tanaman berumur 35 hari setelah tanam, masing-masing jenis pupuk diberikan sekaligus (dosis penuh). Jenis Pupuk dapat dilihat pada Gambar 3.
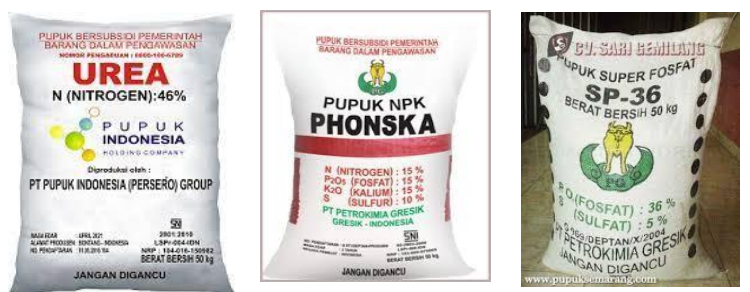

Gambar 3. Pupuk dasar

\section{Pengairan}

Pengairan dilakukan pada saat tanaman padi berumur 8 hari setelah tanam untuk mendukung pertumbuhan akar tanaman dan anakan baru. Kemudian pada saat tanaman sudah menginjak fase primordia sampai fase bunting lahan digenangi setinggi $5 \mathrm{~cm}$ untuk menekan pertumbuhan anakan baru, saat fase pengisian biji ketinggian air dipertahankan sekitar $3 \mathrm{~cm}$. Setelah fase pengisian biji, lahan diari dan dikeringkan secara bergantian.

\section{Pengendalian hama dan penyakit}

Hama yang menyerang tanaman padi sawah yaitu walang sangit. walang sangit merupakan hama yang merusak 
bulir padi pada fase pemasakan. Fase pertumbuhan tanaman padi yang rentan terhadap serangan walang sangit adalah dari keluarnya malai sampai matang susu. Kerusakan yang ditimbulkan oleh serangan walang sangit yaitu gabah menjadi hampa, beras berubah warna dan mengapur. Hama walang sangit dikendalikan dengan melakukan penyemprotan pestisida ke tanaman yang terserang hama.

\section{HASIL DAN PEMBAHASAN}

Kegiatan ini dilaksanakan pada bulan Oktober 2017. Kegiatan yang dilakukan meliputi 2 kegiatan yakni penyuluhan dan pembinaan terkait pemanfaatan teknologi pengelolaan tanaman. Sebelum dilakukan penyuluhan terlebih dahulu menyiapkan bahan dan alat yang digunakan untuk menentukan atau memilih benih padi yang unggul, pengolahan tanah, persemaian, penanaman sistem tanam jajar 4:1, pemupukan, pengairan pengendalian hama atau penyakit. Setelah menyiapkan bahan dan alat tersebut, barulah melakukan penyuluhan kepada masyarakat di kantor desa Peruan Dalam pada tanggal 7 Oktober 2017, jam 19.00 WIB sampai 22.00 WIB dengan bantuan mahasiswa/i STKIP Persada Khatulistiwa Sintang yang sedang melaksanakan kegiatan KKM dan PPL di desa Peruan Dalam.

Kegiatan ini dihadiri oleh puluhan masyarakat yang berada di desa Peruan Dalam. Masyarakat termotivasi mengikuti kegiatan ini karena masyarakat ingin memperoleh informasi terkait pemanfaatan teknologi pengelolaan tanaman dalam rangka meningkatkan produksi padi terutama padi sawah yang selama ini produksi padi mengalami kemerosotan.

Pada saat kegiatan berlangsung dihadiri juga beberapa pejabat desa seperti:
a. Kepala Desa Peruan Dalam
b. Sekretaris desa
c. Ketua Adat
d. Kepala Dusun
e. Ketua RT
f. Ketua Kelompok Tani

Pejabat desa Peruan Dalam sangat antusias mengikuti kegiatan penyuluhan tersebut. Beberapa masyarakat juga ikut memberikan pertanyaan atau sanggahan terkait materi yang disampaikan. Adapun pertanyaan terkait bagaimana memilih benih yang unggul dan bagaimana cara pemberian pupuk yang bagus untuk tanaman padi. Ternyata selama ini masyarakat belum pernah menerapkan pemilihan benih padi yang unggul dengan indikator garam dan telur. Selama ini mereka langsung mengambil padi yang 
ditanam sebelumnya dan merendam dalam air kurang lebih 2 hari sebelum ditanam. Masyarakat tidak melakukan seleksi benih padi yang unggul. Hasilnya tentu saja akan mempengaruhi produksi padi masyarakat. Dengan kegiatan $\mathrm{PkM}$ ini masyarakat mendapatkan informasi baru terkait pemilihan benih padi yang unggul.

Disisi lain, penggunaan pupuk dasar seperti urea dan Phonska masih jarang digunakan untuk mempuk padi dalam rangka meningkatkan produksi padi terutama padi sawah. Hal ini menyebabkan produksi padi sawah pada masyarakat Peruan Dalam tidak dapat maksimal. Dengan kegiatan $\mathrm{PkM}$ ini masyarakat Peruan Dalam menyadari betul dampak penggunaan pupuk dalam produksi padi mereka, sehingga mereka termotivasi untuk menggunakan pupuk tersebut untuk meningkatkan produksi padi.

Setelah melakukan penyuluhan, dilanjutkan pembinaan kepada masyarakat Peruan Dalam terkait pemanfaatan teknologi pengelolaan tanaman. Pembinaan itu dibantu oleh mahasiswa/i STKIP Persada Khatulistiwa Sintang yang melaksanaan kegiatan PPL dan KKM selama 3 bulan.

Hasil kegiatan PkM yang dilakukan di desa Peruan Dalam sangat bermanfaat bagi masyarakat. Masyarakat sudah mulai melihat perubahan hasil panen padi mereka. Padi yang ditanam tumbuh dengan subur yang nantinya akan dapat berdampak pada peningkatan produksi padi terutama padi sawah. Kegiatan penyuluhan dapat dilihat pada Gambar 4.
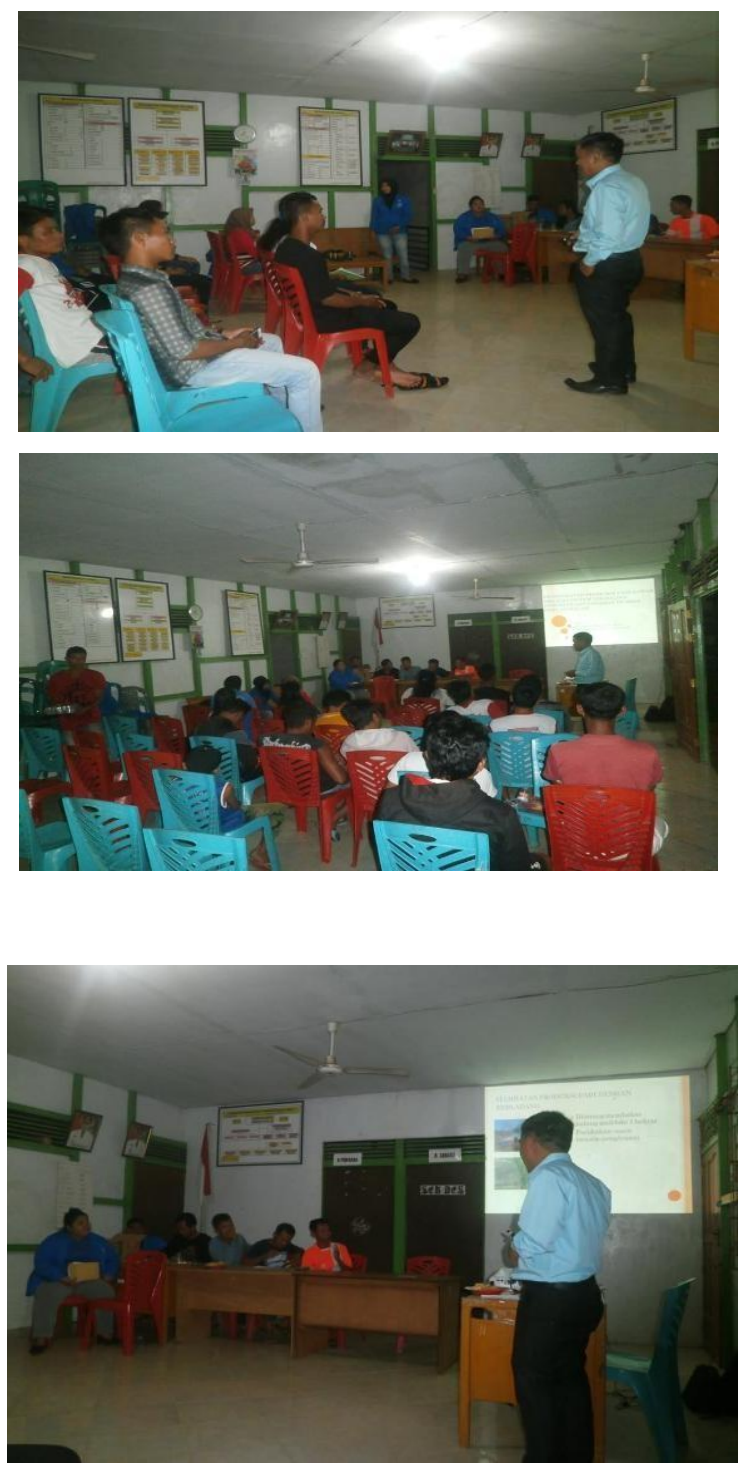

Gambar 4. Kegiatan Penyuluhan

\section{SIMPULAN}

Program kegiatan masyarakat (PkM) yang dilaksanakan di desa Peruan 
Dalam dapat diselenggarakan dengan baik dan berjalan dengan lancar sesuai dengan rencana kegiatan yang telah disusun meskipun belum semua peserta PkM menguasai dengan baik materi yang disampaikan. Kegiatan ini mendapat sambutan sangat baik terbukti dengan keaktifan peserta mengikuti kegiatan PkM dengan tidak meninggalkan tempat sebelum waktu penyuluhan berakhir.

Berdasarkan evaluasi yang telah dilakukan dapat diajukan beberapa saran sebagai berikut:

1. Waktu pelaksanaan kegiatan PkM perlu ditambah agar tujuan kegiatan dapat tercapai sepenuhnya, tetapi dengan konsekuensi penambahan biaya pelaksanaan. Oleh karena itu biaya PkM sebaiknya tidak sama antara beberapa tim pengusul proposal, mengingat khalayak sasaran yang berbeda pula.

2. Adanya kegiatan lanjutan yang berupa pelatihan sejenis selalu diselenggarakan secara periodik sehinga dapat meningkatkan kemampuan masyarakat dalam meningkatkan produksi padi sawah.
Bobihoe, J., 2013. Sistem tanam padi jajar legowo. Balai Pengkajian Teknologi Pertanian (BPTP) Jambi. Balai Besar Pengkajian Dan Pengembangan Teknologi Pertanian. Badan Penelitian Dan Pengembangan Pertanian Kementrian Pertanian. 22 hal.

Koswara, S. 2009. Teknologi pengolahan beras (teori dan praktek). Ebok pangan. Com. http://tekpan.unimus.ac.id/wpcontent/uploads/2013/07/Tekno. Di akses tanggal 29 Agustus 2017.

Kristamtini, dkk. 2011. Sistem tanam jajar legowo (tajarwo) selama pelaksanaan SLPTT padi tahun 2009 di Bantul. Prosiding Seminar Ilmiah Hasil Penelitian Padi 2010. Balai Besar Penelitian Tanaman Padi. Badan Penelitian dan Pengembangan Pertanian. Kementrian Pertanian. 1173 hal.

Lalla, H. Saleh, Ali, Saadah. 2012. Adopsi petani padi sawah terhadap sistem tanam jajar legowo 2:1 di Kecamatan PolongBangkeng Utara, Kabupaten Takalar. J. Sains dan Teknologi. $3(12): 255-264$.

\section{DAFTAR PUSTAKA}

